\title{
B-cell Function and Blood Glucose Control in Insulin Dependent Diabetics within the First Month of Insulin Treatment
}

\author{
O. K. Faber and C. Binder \\ Hvidøre Hospital, Klampenborg, Denmark
}

Summary. Seventeen insulin dependent diabetics were studied after two to four weeks of insulin treatment in a situation approximating to their normal daily life. Some endogenous insulin secretion, assessed by plasma C-peptide determinations, was present in all. Plasma C-peptide concentration was positively correlated with the blood glucose concentration and increased after breakfast, lunch and dinner $(p<0.01)$; both peak values and relative increases were lower than those observed in normal subjects $(p<0.01)$. The highest insulin secretory capacity was found in subjects with the least unstable blood glucose concentration $(\mathrm{r}=0.57, \mathrm{p}<$ 0.03 ), and these patients required the smallest insulin doses $(r=0.54, P<0.04)$. These findings demonstrate the metabolic importance of a preserved B-cell function.

Key words: Insulin dependent diabetes mellitus, glucose, C-peptide, insulin, insulin treatment, insulin secretion.

It is now well established that proinsulin is converted within the B-cells to insulin and C-peptide [1, 2]. Insulin and $C$-peptide are subsequently secreted into the portal circulation in equimolar amounts $[3$, 4]. In contrast to insulin, C-peptide is not significantly degraded by the liver [5]. Measurements of peripheral C-peptide concentrations can, therefore, be used as a measure of B-cell function during insulin treatment.

By means of C-peptide determinations, preserved B-cell function has been reported in some insulin dependent diabetics $[6,7,8,9,10,11,12]$. Using a C-peptide assay with an increased sensitivity it was possible to demonstrate preserved B-cell function in all of 17 insulin dependent diabetics during the first month of treatment [13]. It was also shown that $\mathrm{C}$-peptide concentration increased in response to meals and an oral glucose load [13]. This suggested that this, even minimal, B-cell function may play a role in blood glucose control. It was the purpose of this study to test this hypothesis.

\section{Material and Methods}

Seventeen subjects with insulin dependent diabetes mellitus were studied after two to four weeks of insulin treatment, which was started on the day of referral to the hospital. None of the patients were in coma at the time of diagnosis. The age and sex of the patients are shown in the table. The clinical diagnosis of insulin dependent diabetes mellitus was established at the time of diagnosis according to the following criteria: random blood glucose concentration higher than $12 \mathrm{mmol} / \mathrm{l}$, significant ketonuria (more than or equal to ++ with Ketostix ${ }^{(\pi)}$ ), body weight below $110 \%$ of the ideal for sex and height (14) and age less than fifty years. The seventeen patients comprised all such subjects referred to the Hvidøre Hospital during the period 1.6.1974 to 31.5.1975. For comparison 10 normal subjects were studied. Their mean body weight was $99 \%$ of ideal (range 94-104\%). None of the subjects studied received medication other than insulin.

The patients were examined in a situation as near to their normal daily life as possible. They were ambulant, but took no significant exercise between samples. After an overnight fast free-flowing venous blood samples were taken 30,10 and 0 minutes before and 30, 60, 90 and 120 minutes after breakfast, lunch and dinner. Seven $\mathrm{ml}$ samples of blood were placed into plastic tubes containing $700 \mu \mathrm{I}$ of 
trasylol-heparin mixture (Trasylol Bayer 5000 $\mathrm{KIE} / \mathrm{ml}$ and Heparin Novo $5000 \mathrm{IE} / \mathrm{ml}$ in relative proportions 10:1 volume/volume). The amount and distribution of calories were in accordance with the usual diet of the patients. Ten patients were treated with Lente, four with Monotard ${ }^{\circledR}$ and three with NPH insulin, administered as one dose just before breakfast. The normal subjects followed the same protocol, including the diabetic diet.

Blood glucose concentration (BG) was measured by a glucose oxidase method. Plasma insulin concentration (IRI) was measured radioimmunologically using ethanol for the precipitation of the antigenantibody complex [15]. Plasma C-peptide concentration (CP) was measured by the method of Heding [16], employing the antibody M 1230 [17]. The within and between assay coefficients of variation for C-peptide were $3.2 \%$ and $9.6 \%$, respectively [17]. All samples from one subject were analysed in the same assay. A mean amplitude of glycaemic excursions was calculated from the diurnal blood glucose profile in both diabetic and normal subjects, as described by Service et al. [18]. It was termed the "meal related mean amplitude of glycaemic excursions" (MAGE $\mathrm{M}_{\mathrm{M}}$ ), because it was calculated from BG values covering $2 \frac{1}{2}$ hours around the three main meals. It was used as an index of instability of blood glucose concentration. The mean values of $\mathrm{BG}, \mathrm{CP}$ and IRI were calculated from the 21 samples included in each diurnal profile. The mean $\mathrm{CP}$ was used as a measure of the functional B-cell secretory capacity.

Comparison of the results from the patients and normal subjects was analysed statistically by means of the Mann-Whitney rank sum test for unpaired data. Significance of correlations was tested by means of Spearman's rank correlation test. Five percent was accepted as the level of statistical significance.

\section{Results}

The average diurnal profiles of $\mathrm{BG}$, IRI and $\mathrm{CP}$ from normal and diabetic subjects are shown in Figure 1 and mean individual values from the diabetics are listed in the table.

\section{Blood Glucose Concentration $(B G)$}

The average BG was higher throughout the day in the diabetics ( $p<0.01$ at all times) and showed greater variation than observed in the normal subjects. In the diabetics the greatest increase in $\mathrm{BG}$ was noted between the fasting and 90 minutes post- prandial samples. The highest average $\mathrm{BG}$ was $13.2 \mathrm{mmol} / \mathrm{l}$ after breakfast. Peak average BG after lunch and dinner were 7.7 and $10.4 \mathrm{mmol} / \mathrm{l}$ respectively. The individual mean $\mathrm{BG}$ exceeded the normal range from 4.0 to $5.6 \mathrm{mmol} / \mathrm{l}$ except for two patients.

\section{Plasma Insulin Concentration (IRI)}

Average fasting IRI was identical in normals and diabetics (mean 0.07, range normals: $0.05-0.10$, range diabetics: $0.00-0.12 \mathrm{pmol} / \mathrm{ml}$ ). In the normals IRI increased in all subjects after the three meals $(\mathrm{p}<0.01)$ to average peak values of 0.34 , 0.24 and $0.29 \mathrm{pmol} / \mathrm{ml} 60$ minutes after the start of the meals. The average relative increases (i.e. increase over basal divided by basal) were 4.3, 3.2 and 2.7 respectively.

In the diabetics IRI increased to an average peak value of $0.21 \mathrm{pmol} / \mathrm{ml} 90$ to 120 minutes after breakfast. Thereafter IRI gradually declined with small but statistically significant $(\mathrm{p}<0.01)$ increases to average peaks of 0.20 and $0.17 \mathrm{pmol} / \mathrm{ml} 60$ and 90 to 120 minutes after lunch and dinner respectively. The average relative increases were $2.0,0.1$ and 0.2 respectively.

The individual mean IRI showed a big overlap between normal and diabetic subjects, the average value for the two groups being 0.16 (range $0.11-0.19$ ) and 0.15 (range $0.06-0.24$ ) $\mathrm{pmol} / \mathrm{ml}$ respectively. The IRI of the diabetics represents the sum of endogenous and exogenous insulin.

Thus IRI in the diabetics lacked the brisk rise after meals and was higher between meals compared with the values obtained in the normal subjects.

\section{Plasma C-peptide Concentration (CP)}

In the normal subjects average fasting CP was 0.36 , range $0.25-0.56, \mathrm{pmol} / \mathrm{ml}$. CP increased in all subjects after meals $(\mathrm{p}<0.01)$ to average peak values of $1.14,0.98$ and $1.18 \mathrm{pmol} / \mathrm{ml}, 60$ minutes postprandially. Average relative increases were 2.56, 2.01 and 2.45 after the three meals, respectively.

In the diabetics average fasting CP was approximately half of that found in the normal subjects $(0.17$, range $0.08-0.45 \mathrm{pmol} / \mathrm{ml}, \mathrm{p}<0.01)$. Statistically significant variations in $\mathrm{CP}$ were observed in all the diabetics since the difference between the highest and lowest $\mathrm{CP}$ in any single patient was greater than eleven times the within assay standard deviation (vide supra).

Statistically significant increases in $\mathrm{CP}$ were observed after the meals ( $p<0.01$ after all three meals). The average peak $\mathrm{CP}$ was $0.32,0.24$ and 
Table 1. Individual clinical data and blood glucose, plasma C-peptide and plasma insulin concentrations from diurnal studies in 17 insulin dependent diabetics, together with average values from 10 normal subjects. Individual mean values were calculated from the 21 samples included in each diurnal profile. Calculated values of the meal related mean amplitude of glycaemic excursions (MAGE ${ }_{\mathrm{L}}$ ) are also shown

\begin{tabular}{|c|c|c|c|c|c|c|c|}
\hline sub- & & $\begin{array}{l}\text { age at } \\
\text { onset }\end{array}$ & $\begin{array}{l}\text { insulin } \\
\text { dose }\end{array}$ & $\begin{array}{l}\text { blood glucose } \\
\mathrm{mmol} / \mathrm{l}\end{array}$ & $\mathrm{MAGE}_{\mathrm{M}}$ & $\begin{array}{l}\text { C-peptide } \\
\mathrm{pmol} / \mathrm{ml}\end{array}$ & $\begin{array}{l}\text { insulin } \\
\mathrm{pmol} / \mathrm{ml}\end{array}$ \\
\hline & $\operatorname{sex}$ & yeals & 1. $\mathrm{u} / \mathrm{kg} / \mathrm{L}+\mathrm{I}$ & range & & mean & mean \\
\hline
\end{tabular}

Diabetic subjects

\begin{tabular}{lllllllllll}
\hline JL & M & 13 & 0.16 & 6.2 & $2.8-9.4$ & 4.3 & 0.27 & $0.08-0.40$ & 0.06 & $0.02-0.09$ \\
MR & F & 49 & 0.52 & 8.3 & $2.4-14.6$ & 8.6 & 0.14 & $0.06-0.21$ & 0.15 & $0.00-0.33$ \\
MC & M & 36 & 0.31 & 8.3 & $4.0-14.6$ & 5.5 & 0.16 & $0.08-0.24$ & 0.10 & $0.04-0.15$ \\
OS & M & 39 & 0.16 & 8.4 & $4.8-13.2$ & 5.8 & 0.55 & $0.42-0.79$ & 0.16 & $0.08-0.25$ \\
IN & F & 15 & 0.74 & 8.7 & $4.7-14.1$ & 6.3 & 0.16 & $0.10-0.21$ & 0.21 & $0.05-0.35$ \\
CZ & M & 25 & 0.61 & 8.7 & $2.8-14.6$ & 8.6 & 0.19 & $0.13-0.29$ & 0.24 & $0.02-0.60$ \\
GL & M & 29 & 0.30 & 9.6 & $6.5-14.7$ & 6.1 & 0.18 & $0.14-0.30$ & 0.17 & $0.06-0.24$ \\
AO & F & 33 & 0.47 & 7.5 & $3.3-15.9$ & 8.3 & 0.07 & $0.05-0.11$ & 0.16 & $0.09-0.25$ \\
TE & M & 27 & 0.32 & 9.2 & $5.6-16.0$ & 4.3 & 0.27 & $0.17-0.47$ & 0.13 & $0.06-0.19$ \\
FH & M & 48 & 0.63 & 11.1 & $5.3-16.9$ & 8.1 & 0.08 & $0.06-0.11$ & 0.14 & $0.05-0.21$ \\
PL & M & 47 & 0.24 & 5.0 & $1.8-8.3$ & 3.6 & 0.14 & $0.07-0.28$ & 0.25 & $0.11-0.22$ \\
BA & M & 25 & 0.23 & 10.7 & $8.5-13.4$ & 3.0 & 0.32 & $0.20-0.46$ & 0.11 & $0.05-0.16$ \\
PN & M & 37 & 0.46 & 11.1 & $7.6-15.8$ & 3.9 & 0.25 & $0.17-0.42$ & 0.16 & $0.03-0.23$ \\
BP & M & 44 & 0.42 & 7.5 & $4.0-11.6$ & 5.3 & 0.31 & $0.19-0.46$ & 0.22 & $0.12-0.29$ \\
ON & M & 30 & 0.40 & 7.6 & $3.8-15.5$ & 7.7 & 0.23 & $0.12-0.45$ & 0.15 & $0.09-0.23$ \\
FK & M & 13 & 0.17 & 9.0 & $5.8-13.9$ & 7.7 & 0.22 & $0.11-0.32$ & 0.13 & $0.06-0.19$ \\
HR & M & 35 & 0.31 & 5.3 & $2.9-9.0$ & 4.3 & 0.21 & $0.12-0.37$ & 0.20 & $0.09-0.26$ \\
\hline Mean & & 32 & 0.38 & 8.4 & & 6.0 & 0.22 & & 0.15 & \\
Range & $13-49$ & $0.16-0.74$ & $5.0-11.1$ & & $3.0-8.6$ & $0.07-0.55$ & & $0.06-0.24$ \\
\hline
\end{tabular}

\begin{tabular}{lllllll}
\hline \multicolumn{7}{c}{ Normal Subjects } \\
\hline Mean & 28 & 0 & 4.8 & 1.4 & 0.66 & 0.16 \\
Range & $22-44$ & & $4.0-5.6$ & $0.6-2.6$ & $0.42-0.91$ & $0.11-0.19$ \\
\hline
\end{tabular}
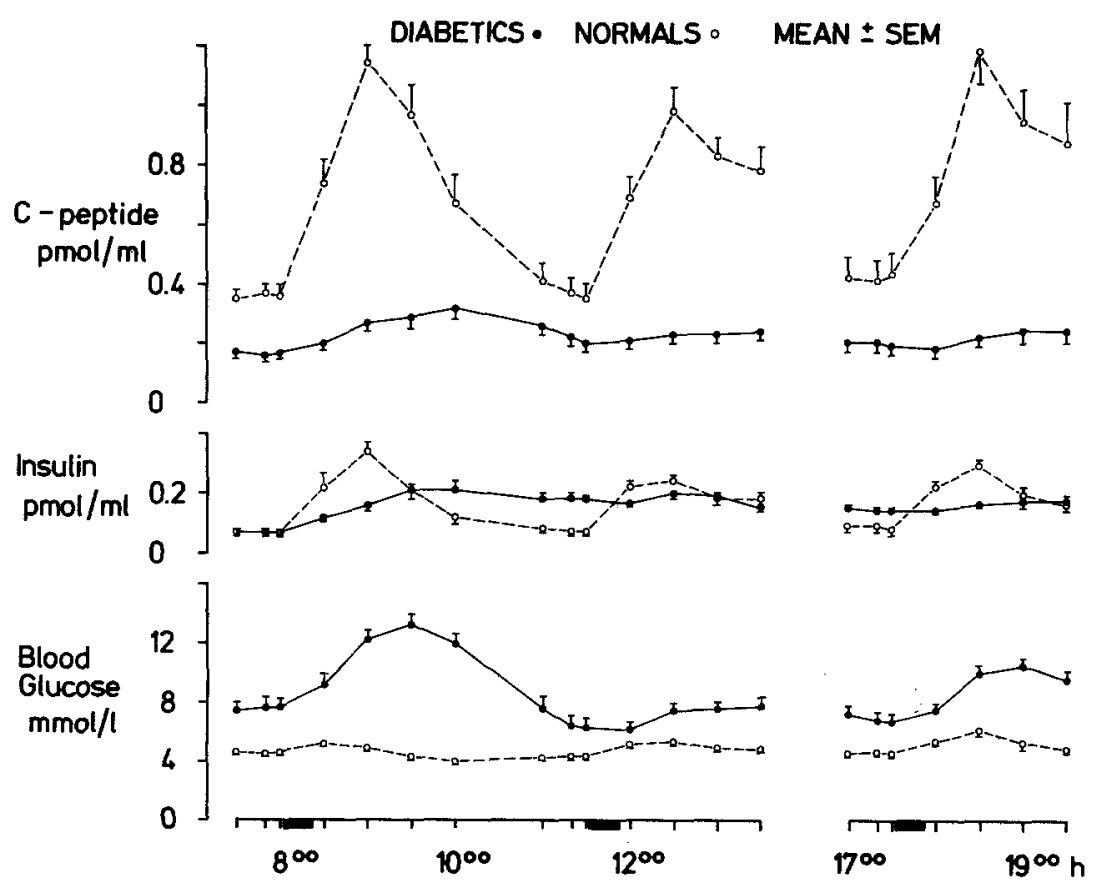

Fig. 1. Average ( \pm SEM) diurnal profiles of blood glucose, insulin and C-peptide from 17 diabetics (closed circles) and 10 normal subjects (open circles). Black bars indicate meals 


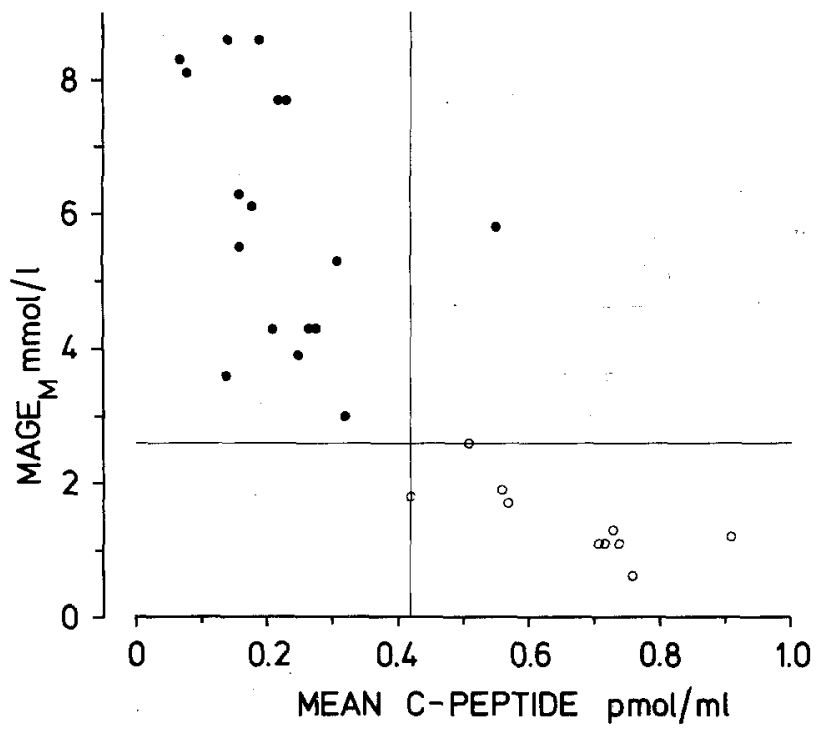

Fig. 2. Correlation between mean C-peptide and meal related mean amplitude of glycaemic excursions $\left(\mathrm{MAGE}_{\mathrm{M}}\right)$ in 17 diabetics (closed circles) and 10 normal subjects (open circles) $r=-0.57, p<0.03$ for diabetics $\mathrm{r}=-0.72, \mathrm{p}<0.03$ for normals

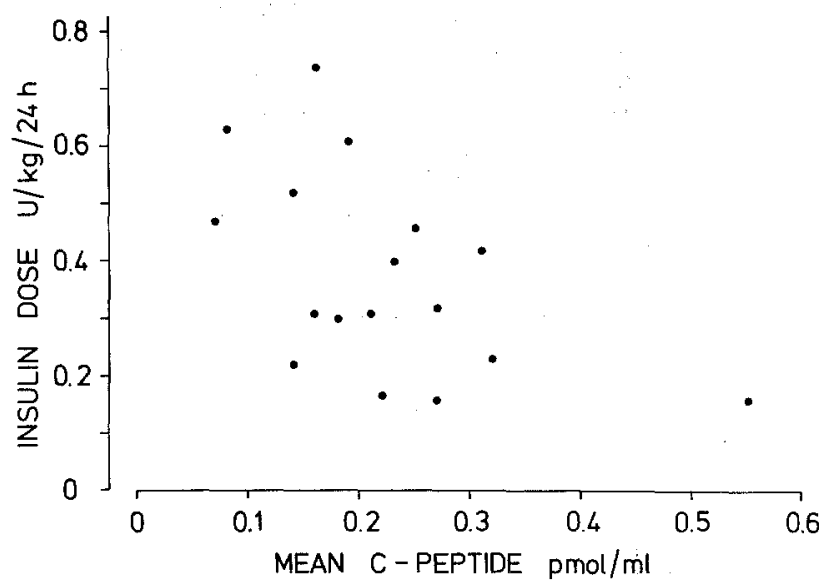

Fig. 3 Correlation between mean C-peptide and insulin dose in 17 diabetics $\mathrm{r}=-0.54, \mathrm{p}<0.04$

$0.24 \mathrm{pmol} / \mathrm{ml} 120,120$ and 90 to 120 minutes after the three meals, respectively. Average relative increases were $1.04,0.23$ and 0.39 respectively.

Peak values as well as relative increases were smaller in the diabetics $(\mathrm{p}<0.01)$ and peak values were observed later in the diabetics $(p<0.01$ after breakfast and dinner; $p<0.05$ after lunch). The individual mean $\mathrm{CP}$ was higher in the normal subjects (mean 0.66 , range $0.42-0.91 \mathrm{pmol} / \mathrm{ml}$ ) than in the diabetics (mean 0.22 , range $0.07-0.55 \mathrm{pmol} / \mathrm{ml}$ ) $(p<0.01)$, with only one diabetic subject overlapping the normal range.

$\mathrm{CP}$ and IRI paralleled the glucose excursions in the normals. Highly significant correlations were found in all the normals between IRI and CP (mean $r=0.87$; range $0.75-0.96$ )

In the individual diabetics there was no correlation between IRI and CP, whereas BG and CP were directly correlated, statistically significant so in 12 of the 15 diabetics (mean $r=0.50$; range $0.25-0.92$ ).

MAGE $_{M}$ was correlated inversely with the mean $\mathrm{CP}$ in both normals $(\mathrm{r}=-0.72 ; \mathrm{p}<0.03)$ and in the diabetics $(r=-0.57 ; p<0.03)$, with smaller $\mathrm{MAGE}_{\mathrm{M}}$ in individuals with higher mean $\mathrm{CP}$ (Fig. 2). Also the insulin dose was correlated inversely with the mean CP $(r=-0.54 ; p<0.04)$, with increasing mean $\mathrm{CP}$ corresponding to decreasing doses of exogenous insulin (Fig. 3).

\section{Discussion}

Peripheral venous C-peptide concentration was originally proposed as a measure of pancreatic B-cell secretion by Melani et al. [19]. This hypothesis has been substantiated $[4,20]$. The close correlation between $\mathrm{C}$-peptide and insulin concentrations found in the 10 normal subjects during normal daily life further supports this concept.

Using a C-peptide radioimmunoassay Block et al. [9] were able to demonstrate endogenous insulin secretion during the remission period. Recent results indicate that most insulin treated diabetics, when tested shortly after the start of insulin treatment, have a certain degree of preserved B-cell function and that this may last for several years $[10,12,21$, 22].

All seventeen insulin dependent diabetics in this study secreted significant amounts of C-peptide during a near normal daily life situation. The disappearance rate of C-peptide is not different in diabetic and normal subjects (Faber et al., in preparation) and is not influenced by the C-peptide concentration [23]. The average $67 \%$ reduction in the mean $\mathrm{C}$ peptide during the diurnal study in the diabetic patients therefore indicates an equally large reduction in endogenous insulin secretion. The true B-cell failure is even more pronounced considering the hyperglycaemia. However, this calculation is only valid with an unchanged secretory relation between C-peptide and insulin.

Cross-reactivity of human proinsulin in the Cpeptide assay may be a problem. In the assay used, human proinsulin is removed by incubation with excess of insulin antibodies bound to sepharose [16]. Insulin treated patients with preserved endogenous insulin secretion may have a high concentration of human proinsulin due to binding of proinsulin to cir- 
culating endogenous insulin antibodies [24]. This will reduce the efficiency of the removal of proinsulin by the solid phase antibody. However, only one patient (MR) had significant amounts of insulin antibodies, as determined by the method of Christiansen [25]. The insulin antibody concentration was very low in this patient and her C-peptide curve did not differ from those found in the other patients. Furthermore, human proinsulin cross-reacts less than $15 \%$ on a molar basis with C-peptide, when measured with the antibody M 1230 (unpublished observation). The contribution of endogenous human proinsulin to the plasma C-peptide concentration is therefore considered to be negligible.

Peak CP after the meals was delayed by one hour in the diabetic patients. This could alone be a consequence of the high and stimulatory $\mathrm{BG}$ in the patients and does not necessarily imply a qualitative defect in insulin release of the single $\mathrm{B}$-cell. The correlation between individual $\mathrm{BG}$ and $\mathrm{CP}$ values in the diabetics demonstrates that the preserved B-cells are still capable of modulating their secretion. These observations spcak against a major defect in the stimulus-secreting coupling in the B-cells.

The correlation between mean $\mathrm{CP}$ and "meal related mean amplitude of glycaemic excursions" $\left(M_{A G E}\right)$ in normal subjects shows that a higher average insulin output implies smaller BG excursions. In the insulin dependent diabetics C-peptide was significantly correlated with $\mathrm{MAGE}_{M}$ as in the normal subjects. This demonstrates the metabolic importance of a preserved B-cell function, which also appears from the inverse correlation between insulin dose and mean $\mathrm{CP}$, with the highest doses given to those with the lowest mean $\mathrm{CP}$. Both mean $\mathrm{CP}$ and $\mathrm{MAGE}_{\mathrm{M}}$ were calculated from values that covered only $8 \frac{1}{2}$ hours of the day. The greatest excursion of $\mathrm{CP}, \mathrm{BG}$ and IRI are, however, to be expected during this time.

Both endogenous and exogenous insulin contributed to the changes in IRI. Thus, peak IRI was significantly correlated with the insulin dose $(\mathrm{r}=$ $0.59 ; \mathrm{p}<0.02$ ) as also found by Ginsberg et al. [26]. The mean IRI was, however, not correlated with the insulin dose, suggesting some endogenous contribution. This endogenous contribution is evident when considering the significant increase in IRI after lunch and after dinner. Any contribution of exogenous insulin to this increase after dinner is unlikcly, because the peak IRI induced by intermediatc acting insulin preparations injected subcutaneously in the morning is usually observed before 17.00 hours $[26,27]$.

The metabolic significance of the preserved B-cell function suggests that, when aiming at a bet- ter control of the metabolic disturbances in insulin dependent diabetes mellitus, measures to restore or improve B-cell function should be considered.

Acknowledgement. We are indebted to Miss B. Mathiassen and Miss J. Falk for their technical assistance.

\section{References}

1. Steiner, D.F., Oyer, P.E.: The biosynthesis of insulin and a probable precursor of insulin by a human islet cell adenoma. Proc. Natl. Acad. Sci. USA 57, 473-480 (1967)

2. Steiner, D.F., Clark, J. L., Nolan, C., Rubenstein, A.H., Margoliash, E., Aten, B., Oyer, P.E.: Proinsulin and the biosynthesis of insulin. Recent Progress in Hormone Research, Vol. 25 p. 207 . New York: Academic Press 1969

3. Rubenstein, A. H., Block, M. B., Starr, J., Melani, F., Steiner, D.F.: Proinsulin and C-peptide in blood. Diabctes 21, (Suppl. 2) 661-672 (1972)

4. Horwitz, D. L., Starr, J.L., Mako, M. E., Blackard; W. G., Rubenstein, A.H.: Proinsulin, insulin, and C-peptide concentrations in human portal and peripheral blood. J. Clin. Invest. 55, 1278-1283 (1975)

5. Stoll, R.W., Touber, J.L., Menahan, L.A., Williams, R. H.: Clearance of porcine insulin, proinsulin, and connecting peptide by the isolated rat liver. Proc. Soc. Fxp. Biol. 133, 894-896 (1970)

6. Block, M. B., Mako, M.E., Stciner, D. F., Rubenstein, A.H.: Circulating C-peptide immunoreactivity. Studies in normals and diabetic patients. Diabetes 21, 1013-1026 (1972)

7. Rubenstein, A.H., Clark, J.L., Melani, F., Steiner, D.F.: Secretion of proinsulin C-peptide by pancreatic $\beta$ cells and its circulation in blood. Nature 224, 697-699 (1969)

8. Block, M. B., Mako, M.E., Steiner, D. F., Rubenstcin, A. H.: Diabctic ketoacidosis: Evidence for C-peptide and proinsulin secretion following recovery. J. Clin. Endocrinol. Metab. 35, 402-406 (1972)

9. Block., M. B., Rosenfield, R. L., Mako, M. E., Steiner, D. F., Rubenstein, A. H.: Sequential changes in beta-cell function in insulin-treated diabetic paticnts assessed by C-peptide immunoreactivity. N. Engl. J. Med. 288, 1144-1148 (1973)

10. Heding, L. G., Rasmussen, S. M.: Human C-peptide in normal and diabetic subjects. Diabetologia 11, 201-206 (1975)

11. Ikeda, Y., Ando, N., Minami, N., Ide, Y.: B-cell function of insulin-dependent young onset diabetics assessed by C-peptide immunoreactivity. Diabetologia 11, 351-352 (1975)

12. Beischer, W., Heinze, E., Keller, L., Raptis, S., Kerner, W., Pfeiffer, E.F.: Human C-peptide. Part II: Clinical studies. Klin. Wochenschr. 54, 717-725 (1976)

13. Faber, O. K., Binder, C., Markussen, J., Naithani, K., Heding, L. G.: Plasma C-peptide in insulin requiring diabetes mellitus: Diurnal variation and response to oral glucose load during the first 9 months of treatment. Diabetologia 11, 340 (1975)

14. Natvig, H.: Nye Høide - vekttabeller for norske kvinner og menn. Oslo: Landsforeningen for kosthold og helse 1956

15. Heding, L. G.: Determination of total serum insulin (IRI) in insulin-treated diabetic patients. Diabetologia 8, 260-266 (1972)

16. Heding, L. G.: Radioimmunological determination of human C-peptide in serum. Diabetologia 11, 541-548 (1975)

17. Faber, O.K., Markussen, J., Naithani, V.K., Binder, C.: Production of antisera to synthetic benzyloxycarbonyl-C-peptide of human proinsulin. Hoppe-Seylers Z. Physiol. Chem. 357, $751-757$ (1976) 
18. Service, F. J., Molnar, G. D., Rosevear, J. W., Ackerman, E., Gatewood, L.C., Taylor, W.F.: Mean amplitude of glycemic excursions, a measure of diabetic instability. Diabetes 19 , $644-655$ (1970)

19. Melani, F., Rubenstein, A.H., Oyer, P.E., Steiner, D.F.: Identification of proinsulin and C-peptide in human serum by a specific immunoassay. Proc. Natl. Acad. Sci. USA 67, $148-155$ (1970)

20. Heding, L.G., Larsen, U.D., Markussen, J., Jørgensen, K. H., Hallund, O.: Radioimmunoassays for human, pork and ox C-peptides and related substances. Horm. Metab. Res. (Suppl.) 5, 40-44 (1974)

21. Ludvigsson, J., Heding, L. G.: C-peptide in children with juvenile diabetes. Diabetologia 12, 627-630 (1976)

22. Faber, O. K., Binder, C., Hendriksen, C., Drejer, J., Heding, L. G.: Plasma $C$-peptide response to glucagon as a measure of $\beta$-cell function in insulin dependent diabetes mellitus. Diabetes 25, (Suppl. 1) 329 (1976)

23. Faber, O.K., Markussen, J., Naithani, V.K.: C-peptide kinetics in man. Diabetologia 12, 389 (1976)

24. Fink, G., Cresto, J. C., Gutman, R. A., Lavine, R. L., Ruben- stein, A. H., Recant, L.: Plasma proinsulin-like material in insulin treated diabetics. Horm. Metab. Res. 6, 439-443 (1974)

25. Christiansen, Aa.H.: Radioimmunoelectrophoresis in the determination of insulin binding to IgG. Methodological studies. Horm. Metab. Res. 5, 147-154 (1973)

26. Ginsberg, S., Block, M. B., Mako, M.E., Rubenstein, A.H.: Serum insulin levels following administration of exogenous insulin. J. Clin. Endocrinol. Metab. 36, 1175-1179 (1973)

27. Rasmussen, S.M., Heding, L.G., Parbst, E., Vølund, Aa.: Serum IRI in insulin-treated diabetics during a 24-hour period. Diabetologia 11, 151-158 (1975)

Received: October 26, 1976, and in revised form:

February 22, 1977

Dr. O. K. Faber

Hvidøre Hospital

Emiliekildvej 1

DK-2930 Klampenborg

Denmark 